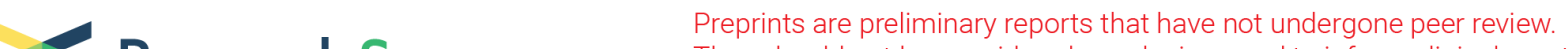 Research Square They should not be considered conclusive, used to inform clinical practice, or referenced by the media as validated information.
}

\section{Distribution Characteristics of Antibiotic Resistance Bacteria and Related Genes in Urban Recreational Lakes Replenished by Different Supplementary Water Source}

\author{
Yongqiang Li \\ Xi'an University of Architecture and Technology \\ Chong-Miao Zhang ( $\nabla$ cmzhang@xauat.edu.cn ) \\ Xi'an University of Architecture and Technology \\ Xiao Mou \\ Shaanxi Institute for Food and Drug Control, Xi'an, 710065, China \\ Peipei Zhang \\ Xi'an University of Architecture and Technology \\ Jie Liang \\ Xi'an University of Architecture and Technology \\ Zhen Wang \\ Xi'an University of Architecture and Technology
}

\section{Research Article}

Keywords: Antibiotic resistance genes (ARGs), Antibiotic resistant bacteria (ARB), Urban recreational waters, Surface water, Reclaimed water

Posted Date: August 30th, 2021

DOl: https://doi.org/10.21203/rs.3.rs-809491/v1

License: (9) This work is licensed under a Creative Commons Attribution 4.0 International License. Read Full License

Version of Record: A version of this preprint was published at Water Science and Technology on January 22nd, 2022. See the published version at https://doi.org/10.2166/wst.2022.018. 


\section{Abstract}

The objective of this study was to investigate the distribution characteristics of antibiotic resistant bacteria (ARB) and antibiotic resistance genes (ARGs) in urban recreational water with different water supply sources, 2 lakes as $\mathrm{XQ}$ and $\mathrm{FQ}$ which represented as surface water and reclaimed water were selected for the study. Water samples were collected from April to November in 2018 to investigate aspects including 8 physical and chemical indexes of waters, resistance degree of 5 different kinds of antibiotics, antimicrobial resistance heterotrophic bacteria content, resistance phenotype, antibiotic resistance gene types and antibiotic resistance strains of species distribution. The results showed that the changes of antibiotic resistance rate of heterotrophic bacteria in 2 lakes to 5 kinds of antibiotics were synchronous with time, and it would reach its maximum in autumn. The detection of $10 \mathrm{ARGs}$ and intt gene in 80 strains screened out from 125 strains of heterotrophic bacteria showed that the detection rate of tetG and tetA genes was relatively high, especially intl, with the rate as high as $90 \%$. In the detection of resistance spectrum, $51.25 \%$ of the resistance bacteria were double-resistance to AMP-CTX. The 80 isolate strains were of 9 genera and 19 species, among which Bacillus cereus, Escherichia coli, Aeromonas veronii, Aeromonas caviae and Raoultella ornithinolytica were the common ARB species in $F Q$ and $X Q$. There was no relatively large differences in the content of ARB, detection rate, and identification of ARGs in 2 lakes. Correlation analysis was used to evaluate the association between the change of water quality indexes and the content of antibiotic resistance bacteria in 2 lakes, and it was found that the water temperature was significantly correlated with the content of ARB in Sulfamethoxazole and Cefotaxime $(p<0.05)$, while there were no other correlations between the changes of other water quality indexes and the content of ARB $(p>0.05)$.

\section{Introduction}

In recent years, antibiotic resistant bacteria (ARB) and Antibiotic resistance genes (ARGs) have got more attention, both as emerging water pollutant (Pruden et al., 2006). Indeed, both of them have been detected in lakes (Low et al.,2016), aquaculture farms (Gao et al.,2012), soil (Tan et al., 2019), wastewater treatment plant (McConnell et al., 2019), as well as in rivers and their sediments (Guo et al., 2018), surface water biofilm (Cynthia and Katharina,2016) and sea sediments (Chen et al., 2013). Compared with the widespread existence of antibiotic resistant bacteria, antibiotic resistance genes is the fundamental reason for the wide spread of bacterial resistance. The spread of ARG in various environmental media through horizontal transfer greatly increases the situation of bacterial antibiotic resistance, posing a threat to the environment and human health. Water is closely related to human life and is an important part of people's production and life. According to some literature reports, however, water is likely to become the source and storage place of pathogenic bacteria and antibiotic resistant bacteria that are harmful to human health (Dong et al.,2019), and intensify their transmission (Fewtrell et al.,2015; Pang, et al., 2016). Previous literature reports mainly focused on fecal indicators, enterovirus, and several pathogenic bacteria such as salmonella in rivers, lakes, and others (Hlavsa et al.,2015). Compare with rivers and lakes, in urban areas with high population density, recreational water 
such as fountains and landscape lakes provide excellent recreational facilities for urban residents (Helena et al., 2015). At the same time, urban recreational water is closely related to people's living. People will contact landscape water in the ways of boating. Also, urban recreational water plays an important role in the city water cycle, and most are connected to the urban river, in many cases, reclaimed water is used as a supply source. However, if there are pathogenic bacteria or other dangerous sources of antibiotic resistance genes in water, it will directly threaten public health. Therefore, it is extremely necessary to analyze the distribution of antibiotic resistant microorganisms in urban landscape water.

As urban recreational water has played a significant role in the continuous expansion of urbanization. At the same time, sufficient attention should be paid to the microbial pollution in the water. Although the urban landscape water develops rapidly at present, the source of water supply is an important problem in practice due to the constraint of its own characteristics. However, some studies have found that although the water source and sediment polluted by human beings have been further treated, it is still likely to play an important role in the re-pollution of water for recreational purposes (Elmahdy et al., 2016). Landscape water is replenished mainly by the surface waters. Due to the shortage of water resources, recycled water gradually as the first selection of urban landscape water supplements (Zhao et al., 2011) for its excellent cyclicity. But the current sewage treatment standards and technology are not able to make the sewage treatment plant to regenerate the processing of the ARB and ARGs effectively in the water. This could lead to reclaimed water has many ARB and ARGs, which might exacerbate the landscape water in the content of resistant bacteria and resistance genes. And then increase the risk of public safety of urban residents (Dong et al., 2019). With the urbanization process and the improvement of people's living standards, the existing role of urban landscape water will become much more important (Cui et al.,2019), and the application of recycled water in landscape water is becoming more and more common. The microbial pollution of recycled water also requires further study, especially whether the supply water sources of different will lead to increased risk of antibiotic resistant bacteria such as microbial, and pose a threat to human health. Research on the different supply water sources of urban landscape water in the ARGs and ARB is of realistic significance.

In this study, 5 kinds of common ARB patterns like: Tetracycline, Sulfa, Ampicillin, Ciprofloxacin, and $\beta$ lactams antibiotic resistance bacteria and some of its corresponding resistance genes as the research target. We took 2 different supply water sources of the landscape waters in Xi 'an as the research object. compared their levels of resistant bacteria in water and the distribution of antibiotic resistance genes, in order to provide the reference for the control of microbial risk.

\section{Material And Methods}

\subsection{Sampling site and sample collection}

The landscape water selected in this study are XQ and FQ lake (Fig. S1, site 1: 108 $59^{\prime} 24.04^{\prime \prime} \mathrm{N}$; $34^{\circ} 15^{\prime} 36.05^{\prime \prime} \mathrm{W}$; site $2: 108^{\circ} 54^{\prime} 24.44^{\prime \prime} \mathrm{N} ; 34^{\circ} 15^{\prime} 7.04^{\prime \prime} \mathrm{W}$ ). They are located in the ancient city of Xi 'an, which are the famous tourist attractions. A large number of tourists go to visit these 2 lakes every day. 
Meanwhile, both lakes have a variety of water entertainment items, such as boating. People have frequent contact with landscape water. XQ lake has an area of about 100,000 square meters and an average water depth of $2 \mathrm{~m}$, surface water is its source of water replenishment. The surface area of FQ lake is about 40000 square meters, with an average depth of 1.5 meters, using reclaimed water as its supply source.

The samples were collected from April to November 2018 in XQ and FQ lake, gather once a month, a total of eight months of the XQ and FQ lake respectively selected the sampling point 5 and 4 samples, they were respectively collected 40 and $32.1 \mathrm{~L}$ water samples was collected below the surface of the water at $50 \mathrm{~cm}$. All the Samples were mixed into a container. Then they were put in aseptic sampling bottles to take back in the laboratory within $6 \mathrm{~h}$, preservation at $4^{\circ} \mathrm{C}$. Experiments will be carried out within $12 \mathrm{~h}$.

\subsection{Water quality parameters}

The contents of total nitrogen and total phosphorus in water samples were determined by the method described in the literature (Guo et al.,2018). After the samples were filtered through the filter membrane, the content of chlorophyll a in water samples was determined by the thermal ethanol method (Chen et al.,2006). The content of dissolved oxygen, $\mathrm{pH}$, and water temperature were determined by reference to literature (Harnisz.,2013).

\subsection{Content determination of heterotrophic bacteria and ARB}

The heterotrophic bacteria and antibiotic resistant bacteria in water samples were counted by membrane method. The heterotrophic bacteria in water samples were counted by the filter membrane method (Novo et al.,2013). After gradient dilution of the water sample, the mixed cellulose filter membrane with a diameter of 0.45 microns was filtered by vacuum extraction. The bacteria trapped in the filter membrane were closely attached to the PCA culture plate and cultured at $30{ }^{\circ} \mathrm{C}$ for $24 \mathrm{~h}$. Colony count was conducted on the culture plate with a number of 20 200 colonies. The average number of colonies was used to calculate the number of heterotrophic bacteria per $100 \mathrm{~mL}$ of the water sample. According to the standards of the American clinical and laboratory standards association (CLSI2017) (Annette w. Fothergill.,2012), Ampicillin (AMP), Sulfamethoxazole (SMZ), Tetracycline (TET), Ciprofloxacin (CIP), and Cefotaxime (CTX) were added into PCA plates to prepare resistance plates, in which the mass concentrations of corresponding antibiotics were $32 \mu \mathrm{g} / \mathrm{mL}, 512 \mu \mathrm{g} / \mathrm{mL}$ and $16 \mu \mathrm{g} / \mathrm{mL}$, respectively. Similarly, the content of 5 kinds of antibiotic resistant bacteria in the water sample was calculated by using the filter membrane method to determine the antibiotic resistant bacteria in the water sample.

\subsection{Isolation and susceptibility testing of antibiotic resistant strains}

Bacterial colonies were randomly selected from PCA plate and activated in LB broth. Then, the plates were crossed for isolation, purification, and preservation of bacterial strains. After using the K-B disc agar diffusion method, selection of sulfamethoxazole (SMZ $300 \mu \mathrm{g}$ ), tetracycline (TET $30 \mu \mathrm{g}$ ), ampicillin (AMP $10 \mu \mathrm{g}$ ), ciprofloxacin (CIP $5 \mu \mathrm{g}$ ), cefotaxime (CTX $30 \mu \mathrm{g}), 5$ kinds of typical antibiotics for heterotrophic 
bacteria were isolated from the antibiotic susceptibility test, determination of inhibition rings diameter, with reference to the Clinical and Laboratory Standards Institute (CLSI) standards to determine the resistance pattern (Annette w. Fothergill,2015).

\subsection{Detection of resistance, integron and strains sequencing analysis}

According to the TaKaRa MiniBEST Bacteria Genomic DNA Extraction Kit Ver. 3.0 Kit instructions, the DNA Extraction and separation of antibiotic resistant strains and save, using 16S rDNA gene sequencing identification, universal primers using Bacteria 27F and 1492R (Harnisz et al., 2018), PCR technology was used to test. After amplification, the products were sent to Sangon Biotech(Shanghai) Co., Ltd. for DNA sequencing. The sequencing results were checked by Bioedit v7.0.9 software, and the obtained 16SrDNA sequences were compared in the GenBank database in the National Center for bio-technology Information (NCBI) to confirm the species.

According to literature reports, 10 kinds of antibiotic resistance genes were identified, including tetracycline resistance genes tet $\mathrm{A}$, tet $\mathrm{B}$, tetG, and tetM: Sulfanilamide resistance genes su/1, sul2, su/ 3 ; $\beta$ lactam type of antibiotic resistance gene $b / a_{\mathrm{TEM}}, b / a_{\mathrm{CTX}-\mathrm{M}}, b / a_{\mathrm{SHV}}$, and Class I integron gene

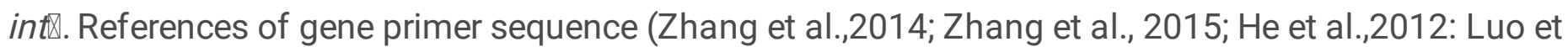
al.,2011) were synthesized by Sangon Biotech(Shanghai) Co., Ltd. Sequences of resistance genes and Reaction conditions shown in table 1.

The antibiotic resistance genes were detected by PCR with Reaction system: $25 \mu \mathrm{L}$ reaction system, template DNA $2 \mu \mathrm{L}$, 10×PCR Buffer $2.5 \mu \mathrm{L}$, dNTP Mixture $2 \mu \mathrm{L}$, TaKaRa Taq $0.2 \mu \mathrm{L}$, upper/lower primers $1 \mu \mathrm{L}$ each, RNase-free Water $16.3 \mu \mathrm{L}$. Reaction conditions: $95^{\circ} \mathrm{C} 8 \mathrm{~min}, 95^{\circ} \mathrm{C} 30 \mathrm{~s}$, annealing $30 \mathrm{~s}, 72^{\circ} \mathrm{C}$ $5 \mathrm{~min}$. The product was detected by $1 \%$ agarose gel electrophoresis (AGE).

Table 1 Primer sequences of the relative resistance genes and Reaction conditions. 


\begin{tabular}{|c|c|c|c|}
\hline Genes & Primer sequences $\left(5^{\prime}-3^{\prime}\right)$ & $\begin{array}{l}\text { Annealing temperature } \\
\left({ }^{\circ} \mathrm{C}\right)\end{array}$ & $\begin{array}{l}\text { Length of } \\
\text { fragment(bp) }\end{array}$ \\
\hline \multirow[t]{2}{*}{ tetA } & F:GCTACATCCTGCTTGCCTTC & \multirow[t]{2}{*}{55} & \multirow[t]{2}{*}{210} \\
\hline & R:CATAGATCGCCGTGAAGAGG & & \\
\hline \multirow[t]{2}{*}{ tetB } & F:TACGTGAATTTATTGCTTCGG & \multirow[t]{2}{*}{61} & \multirow[t]{2}{*}{206} \\
\hline & R:ATACAGCATCCAAAGCGCAC & & \\
\hline \multirow[t]{2}{*}{ tetG } & F:GCACGCTGGTTTGGCTACA & \multirow[t]{2}{*}{56} & \multirow[t]{2}{*}{176} \\
\hline & R:TGGCTGTGATTAGTCTCCTTGA & & \\
\hline \multirow[t]{2}{*}{ tetM } & F:ACAGAAAGCTTATTATATAAC & \multirow[t]{2}{*}{45} & \multirow[t]{2}{*}{171} \\
\hline & R:TGGCGTGTCTATGATGTTCAC & & \\
\hline \multirow[t]{2}{*}{ su/1 } & F:CGCACCGGAAACATCGCTGCAC & \multirow[t]{2}{*}{56} & \multirow[t]{2}{*}{163} \\
\hline & R:TGAAGTTCCGCCGCAAGGCTCG & & \\
\hline \multirow[t]{2}{*}{ sul2 } & F:TCCGGTGGAGGCCGGTATCTGG & \multirow[t]{2}{*}{56} & \multirow[t]{2}{*}{191} \\
\hline & R:CGGGAATGCCATCTGCCTTGAG & & \\
\hline \multirow[t]{2}{*}{ suß } & F:CCCATACCCGGATCAAGAATAA & \multirow[t]{2}{*}{57} & \multirow[t]{2}{*}{143} \\
\hline & R:CAGCGAATTGGTGCAGCTACTA & & \\
\hline \multirow[t]{2}{*}{ bla } & F:AAGCTTATTAGCGTGT & \multirow[t]{2}{*}{55} & \multirow[t]{2}{*}{531} \\
\hline & R:TGTCTATGATCTTGT & & \\
\hline \multirow[t]{2}{*}{ bla $a_{\text {CTX-M }}$} & F:GCTGGTTTCAGAA & \multirow[t]{2}{*}{55} & \multirow[t]{2}{*}{869} \\
\hline & R:TGTGATTAGCTGT & & \\
\hline \multirow[t]{2}{*}{$b / a_{\mathrm{SHV}}$} & F:TGAATACGTTTTCAC & \multirow[t]{2}{*}{55} & \multirow[t]{2}{*}{295} \\
\hline & R:TACCTTGTTATTCAC & & \\
\hline \multirow[t]{2}{*}{ int } & F:GGCTTCGTGATGCCTGCTT & \multirow[t]{2}{*}{57} & \multirow[t]{2}{*}{146} \\
\hline & R:CATTCCTGGCCGTGGTTCT & & \\
\hline \multirow{2}{*}{$\begin{array}{l}16 S \\
\text { rDNA }\end{array}$} & 27F:AGAGTTTGATCCTGCCTCAG & \multirow[t]{2}{*}{56} & 1465 \\
\hline & 1492R:TACGGYTACCTTGTTACGACTT & & \\
\hline
\end{tabular}

2.6. Data analysis

Using Microsoft Excel 2016 and SPSS 23.0 to process and analyze the data, and origin8.5 was used to process and optimize the data images. 2 independent sample tests (Mann-Whitney $U$ test) were used to 
analyze the difference between different samples, and Spearman correlation analysis was used to test the correlation between water quality index and antibiotic resistance rate of samples.

\section{Results}

\subsection{Water quality indicators in 2 lakes}

Eight water quality indicators of the 2 landscape waters were tested, including water temperature, dissolved oxygen, $\mathrm{pH}$, chlorophyll a, total nitrogen, total phosphorus, nitrate nitrogen, and ammonia nitrogen, and the test results were shown in table 2.

Table 2 Water physical and chemical properties of each lake (mean values are in brackets).

\begin{tabular}{|c|c|c|c|c|c|c|c|c|}
\hline Lake & $\begin{array}{l}\text { Temperature } \\
(\mathrm{w})\left({ }^{\circ} \mathrm{C}\right)^{\mathrm{a}}\end{array}$ & $\begin{array}{l}\mathrm{DO} \\
(\mathrm{mg} / \mathrm{L})\end{array}$ & $\mathrm{pH}$ & $\begin{array}{l}\text { Chlorophyll } \\
-\mathrm{a}(\mu \mathrm{g} / \mathrm{L})\end{array}$ & $\begin{array}{l}\mathrm{TN} \\
(\mathrm{mg} / \mathrm{L})\end{array}$ & $\begin{array}{l}\text { TP } \\
(\mathrm{mg} / \mathrm{L})\end{array}$ & $\begin{array}{l}\mathrm{NO}_{3}^{-}- \\
\mathrm{N} \\
(\mathrm{mg} / \mathrm{L})\end{array}$ & $\begin{array}{l}\mathrm{NH}_{4}^{+}- \\
\mathrm{N} \\
(\mathrm{mg} / \mathrm{L})\end{array}$ \\
\hline $\mathrm{FQ}$ & $\begin{array}{l}9.30-31.80 \\
(21.59)\end{array}$ & $\begin{array}{l}7.88- \\
11.37 \\
(9.91)\end{array}$ & $\begin{array}{l}8.14- \\
9.06 \\
(8.66)\end{array}$ & $\begin{array}{l}0.00-21.39 \\
(7.08)\end{array}$ & $\begin{array}{l}1.08- \\
5.47 \\
(3.23)\end{array}$ & $\begin{array}{l}0.02- \\
0.06 \\
(0.03)\end{array}$ & $\begin{array}{l}0.58- \\
1.24 \\
(0.93)\end{array}$ & $\begin{array}{l}0.02- \\
0.78 \\
(0.29)\end{array}$ \\
\hline$X Q$ & $\begin{array}{l}14.40-33.90 \\
(24.43)\end{array}$ & $\begin{array}{l}6.32- \\
9.58 \\
(8.14)\end{array}$ & $\begin{array}{l}7.67- \\
8.53 \\
(8.19)\end{array}$ & $\begin{array}{l}0.00-24.65 \\
(9.42)\end{array}$ & $\begin{array}{l}0.59- \\
2.93 \\
(2.14)\end{array}$ & $\begin{array}{l}0.04- \\
0.09 \\
(0.07)\end{array}$ & $\begin{array}{l}0.27- \\
2.19 \\
(0.88)\end{array}$ & $\begin{array}{l}0.00- \\
0.25 \\
(0.12)\end{array}$ \\
\hline
\end{tabular}

${ }^{\mathrm{a}}$ Temperature(w):water temperature

\subsection{Distribution of antibiotic resistance rate}

The temporal variation of antibiotic resistance rate 2 lakes are shown in figure 1 . The variation trend of heterotrophic bacteria content in 2 lakes is similar, showing an increasing trend with time. The changing trend of antibiotic resistance rate of Tetracycline and Ampicillin in FQ lake was similar over time, and the number of Cefotaxime resistance bacteria had a larger change trend over time, while the change of antibiotic resistance rate of Sulfamethoxazole was less obvious, and the fluctuation of antibiotic resistance rate of ampicillin was more obvious. The antibiotic resistance rate of ampicillin and Cefotaxime in $\mathrm{XQ}$ lake showed the same trend with time, and the fluctuation was the most obvious, it reached its maximum antibiotic resistance rate value in July and September. The antibiotic resistance rate of Sulfamethoxazole was stable and reached the peak in September. By contrast, the antibiotic resistance rate of Ciprofloxacin tended to be stable as a whole, and the antibiotic resistance rate in autumn was higher than that in other seasons. In this study, the overall trend of the changes in the antibiotic resistance rate of bacteria in $\mathrm{FQ}$ and $\mathrm{XQ}$ water was similar, among which the content of ampicillin resistance bacteria in $\mathrm{FQ}$ lake was higher, and the antibiotic resistance rate fluctuated greatly with time. 
The antibiotic resistance rate of ampicillin in FQ lake was the highest in September, which was 15.13\%, the resistance rate of Cefotaxime and Ciprofloxacin reached the maximum value in July and August, which were $11.56 \%$ and $1.97 \%$ respectively. The detection rate of Sulfamethoxazole and Tetracycline resistance bacteria was lower. The antibiotic resistance rate of Sulfamethoxazole in XQ lake varied greatly, in summer it was higher than that in winter, reaching a maximum of $41.07 \%$ in September. Compared with FQ lake, the bacteria resistance to Cefotaxime and Ampicillin in XQ lake were relatively equal, with the highest antibiotic resistance rates of $13.96 \%$ and $12.32 \%$, respectively. The overall trend of antibiotic resistance rate in 2 lakes was similar, and all showed that the antibiotic resistance rate in winter was lower than that in summer. Except for Cefotaxime resistance bacteria in FQ had the highest detection rate in July, the other 4 antibiotic resistant bacteria in 2 lakes all reached the maximum detection rate in autumn. It was found that the antibiotic resistance rates of Tetracycline and Ampicillin were lower in 2 lakes, while the resistance rates of the other 3 antibiotics were higher in 2 lakes. The antibiotic resistance rate in summer and autumn was higher than that in winter. Moreover, the antibiotic resistance rate of bacteria in 2 lakes was higher in August and September than in other months, presenting a significant upward trend.

\subsection{Analysis of antibiotic resistance pattern and antibiotic susceptibility testing}

Based on the detection of antibiotic resistance rate in 2 lakes, $5 \sim 8$ strains were isolated and purified from each sample, and a total of 125 strains of heterotrophic bacteria were isolated, including 63 strains in FQ lake and 62 strains in XQ lake. Then 80 antibiotic resistance strains were screened out from heterotrophic bacteria according to judgment criteria (Annette w. Fothergill, 2015), including 41 strains in FQ lake and 39 strains in XQ lake. The resistance of 80 strains to 5 antibiotics was shown in table 3 . As can be seen from the table, 80 antibiotic resistance strains had different degrees of resistance to 5 different antibiotics, among which the resistance to Ampicillin and Cefotaxime accounted for $93.75 \%$ (75/80) and $58.75 \%(47 / 80)$, respectively. However, the sensitivity to and Tetracycline was higher, with the proportion of antibiotic resistant bacteria being $26.25 \%(21 / 80)$ and $17.50 \%$ (14/80), respectively, with the lowest proportion of antibiotic resistant bacteria being $8.75 \%(7 / 80)$ to ciprofloxacin.

\section{Table 3 antibiotic resistance phenotype of $\mathbf{8 0}$ strains were detected in $\mathbf{2}$ water}

\begin{tabular}{|lllll|}
\hline Antimicrobial agents & sensitive & \multicolumn{3}{c|}{ antibiotic resistance } \\
\cline { 2 - 4 } & Number of strains & isolates\% & Number of strains & isolates\% \\
\hline Ampicillin & 5 & 6.25 & 75 & 93.75 \\
\hline Sulfamethoxazole & 59 & 73.75 & 21 & 26.25 \\
\hline Tetracycline & 66 & 82.50 & 14 & 17.50 \\
\hline Ciprofloxacin & 73 & 91.25 & 7 & 8.75 \\
\hline Cefotaxime & 33 & 41.25 & 47 & 58.75 \\
\hline
\end{tabular}


The analysis of the antibiotic resistance pattern is shown in table 4. The experimental analysis shows that some antibiotic resistant bacteria show single antibiotic resistance, accounting for $13.60 \%(17 / 125)$ and $21.25 \%(17 / 80)$ of the isolated bacteria and the total number of antibiotic resistant bacteria. The antibiotic resistance phenotype of $70 \%$ single-antibiotic resistant bacteria is AMP, followed by SMZ. Most resistant bacteria showed resistance to 2 antibiotics, accounting for 40\% (50/125) and 62.50\% (50/80). The main antibiotic resistance phenotype of the second antibiotic resistance strain was AMP-CTX, and 41 strains were detected, accounting for $82 \%$ of all the double-resistance strains. 13 strains of multiple resistant bacteria, resistance to 3 kinds of common antibiotics, is more common AMP-SMZ-TET phenotype. Among which, 4 strains are resistant to 4 antibiotics, and 2 resistant to all 5 antibiotics. Multiple resistant bacteria resistant to 3, 4, 5 antibiotics were $8.75 \%(7 / 80), 5.00 \%(4 / 80)$, and $2.50 \%$ (2/80), accounting for the proportion of the total number of bacteria screened out were $5.60 \%(7 / 125)$, $3.20 \%(5 / 125), 1.60 \%(2 / 125)$. Among 80 strains, AMP-CTX is the most common resistance pattern, more than half of the isolates antibiotic resistant bacteria had this phenotype. On the whole, the number of strain antibiotic resistant pattern in FQ was higher than $\mathrm{XQ}$, but the proportion of multiple resistant bacteria in $\mathrm{XQ}$ was higher than $\mathrm{FQ}$, the only 2 strains which have 5 resistant patterns were from $\mathrm{XQ}$, and it was found that the detection amount of multiple-antibiotic-resistant bacteria decreased with the increase of antibiotic types.

\subsection{Occurrence of ARGs and integron in strains}

The result of resistance genes detection of 80 ARB isolates from 2 lakes is shown in table 2. Tetracycline antibiotics resistance of bacteria 4 strains and 10 strains respectively. On the resistance gene detects found 2 lakes, tetG detection rate was 100\% (4/4) and 50\% respectively (5/10), known FQ lake tetG gene to their advantage. On the contrary, the detection rate of tetA in XQ lake was slightly higher than that in FQ lake (80\% (8/10) and 75\% (3/4), respectively. The detection rate of tetB and tetM was relatively low, both of the genes were $20 \%(2 / 10)$ in XQ, while neither of them was detected in FQ. In 2 lakes, the Tetracycline positive antibiotic resistant bacteria in FQ lake detected the corresponding resistance gene, and the detection rate of the positive strain resistance gene was $100 \% .1$ of the 10 strains of Tetracycline positive antibiotic resistance bacteria in XQ lake did not detect the corresponding antibiotic resistance gene.

\section{Table 4 Antibiotic resistance patterns for 80 resistance strains in 2 lakes}




\begin{tabular}{|c|c|c|c|c|}
\hline \multirow[t]{2}{*}{$\begin{array}{l}\text { Resistance to } \\
\text { multiplicity }\end{array}$} & \multirow[t]{2}{*}{ resistance phenotype } & \multicolumn{2}{|c|}{$\begin{array}{l}\text { Source and quantity of samples } \\
\text { (strains) }\end{array}$} & \multirow[t]{2}{*}{$\begin{array}{l}\text { Total } \\
\text { (plant) }\end{array}$} \\
\hline & & FQ & $X Q$ & \\
\hline \multirow[t]{5}{*}{$\# 1^{1}$} & AMP $^{2}$ & 6 & 6 & 12 \\
\hline & SMZ & 3 & 2 & 5 \\
\hline & TET & ND & $N^{3}$ & 0 \\
\hline & CIP & ND & ND & 0 \\
\hline & CTX & ND & ND & 0 \\
\hline \multirow[t]{4}{*}{ \# 2} & AMP, SMZ & 4 & 1 & 5 \\
\hline & AMP, TET & 1 & 2 & 3 \\
\hline & AMP, CIP & ND & 1 & 1 \\
\hline & AMP, CTX & 24 & 17 & 41 \\
\hline \multirow[t]{2}{*}{ \# 3} & AMP, SMZ, TET & 2 & 3 & 5 \\
\hline & AMP, CIP, CTX & ND & 2 & 2 \\
\hline \multirow[t]{2}{*}{ \# 4} & AMP, SMZ, TET, CIP & ND & 2 & 2 \\
\hline & AMP, SMZ, TET, CTX & 1 & 1 & 2 \\
\hline \# 5 & $\begin{array}{l}\text { AMP, SMZ, TET, CIP, } \\
\text { CTX }\end{array}$ & ND & 2 & 2 \\
\hline
\end{tabular}

1 \#1: single resistance phenotype, \#2:2 heavy resistance phenotype, \# 3:3 heavy resistance phenotype, \# 4:4 heavy resistance phenotype, \# 5:5 heavy resistance phenotype.

2 AMP: ampicillin, SMZ: sulfamethoxazole, TET: tetracycline, CIP: ciprofloxacin, CTX: cefotaxime.

${ }^{3}$ ND: none detected

Among the 3 tested $\beta$-lactam resistance genes, FQ lake detected 2 types of resistance genes, bla $a_{S H V}$, and $b / a_{\mathrm{TEM}}$, respectively, with the same detection rate of $12 \%(3 / 25) .3$ of the 22 strains screened from XQ lake that are resistant to $\beta$-lactam antibiotics have detected the related antibiotic resistance gene. In addition to the above 2 genes, $b / a_{\mathrm{CTX}-\mathrm{M}}$ has also been detected. The overall detection rate of $b / a_{\mathrm{SHV}}, b / a_{\mathrm{TEM}}$, and bla $a_{\text {CTX-M }}$ in the 2 lakes is low.

In the detection of 3 Sulfa resistance genes of bacteria screened from FQ and XQ lake, it was found that sul 2 in FQ lake had the highest detection rate $26.83 \%(11 / 45)$, while sul1 and sul 3 were the same $12.20 \%$ (5/41). The detection rate of sul1 in XQ lake was $23.07 \%$ (9/39), and that of sul2 was $15.38 \%(6 / 39)$, slightly higher than that of su/3 12.82\% (5/39). FQ and XQ lake respectively screened out 10 and 11 
strains of sulfa resistant bacteria, and the corresponding detection rates of antibiotic resistance genes were $100 \%(10 / 10)$ and $90.90 \%$ (10/11), respectively. Compared with antibiotic resistance genes, the detection rate of int in 2 lakes was the highest, over $90 \%$.

\subsection{Result of species identification}

The identification of bacteria species is shown in figure 3a. It can be seen from the figure that the 80 strains of antibiotic resistant bacteria screened out from 2 lakes can be divided into 9 genera and 19 species, and there are certain differences among various antibiotic resistant bacteria. The dominant antibiotic resistant bacteria of Ampicillin and Cefotaxime are Bacillus cereus, while the antibiotic resistant bacteria of ciprofloxacin are few and only 6 types. The common species of Tetracycline resistant bacteria is Escherichia coli, Bacillus cereus, Escherichia coli, Aeromonas veronii, Aeromonas caviae, and Raoultella ornithinolytica are all antibiotic resistant bacteria in 2 lakes. Among the antibiotic resistant bacteria screened from the sample, Bacillus cereus occupies a certain number advantage over other bacteria, which showed that this kind of bacteria belongs to the main antibiotic resistant bacteria in landscape water, indicating that this bacteria may play a role in promoting the transmission, migration and transformation of antibiotic resistance genes. The identification of multiple resistant bacteria was shown in figure 3b. The results showed that Escherichia coli was the main strain of triple antibiotic resistant bacteria, accounting for $42.86 \%$. Raoultella ornithinolytica was the main resistant strain. Among all multiple resistant bacteria, Escherichia coli has a higher detection rate, and it has detection in triple and quadruple antibiotic resistant bacteria.

\subsection{Correlation between ARB and environmental variables}

Correlation analysis was conducted between the detected concentration of antibiotic resistant bacteria and the synchronized water quality detection indexes of water temperature, dissolved oxygen, $\mathrm{pH}$, chlorophyll a, total phosphorus, total nitrogen, nitrate nitrogen, and ammonia nitrogen. The results were shown in figure 4, where $p<0.01$ indicated significant correlation and $p<0.05$ indicated significant correlation. As can be seen from the figure, the water temperature was significantly correlated with the content of SMZ antibiotic resistant bacteria and CTX antibiotic resistant bacteria in 2 lakes, the total phosphorus content in FQ lake was significantly correlated with the content of ampicillin antibiotic resistant bacteria $(p<0.05)$, and the remaining water quality indexes were not significantly correlated with the concentration of antibiotic resistant bacteria.

\section{Discussion}

The major supplement source of urban landscape water is surface water, however, with the increasing shortage of water resources in recent years, many areas in China have gradually started to use reclaimed water from sewage treatment plants as the source of water replenishment for landscape water (He et al.,2016) to alleviate the increasingly exhausted water resources. However, at the same time, the removal of antibiotic resistant bacteria and antibiotic resistance genes in the regenerated water is not required for 
treatment. If it is directly injected into the landscape water as supplementary water, it may cause pollution to the landscape water and thus affect human health.

\subsection{Distribution characteristics of antibiotic resistant bacteria and resistant pattern}

In the case of the change with time and season, bacteria in the FQ lake have different resistance to 5 kinds of antibiotics, 3 kinds of antibiotic resistance as a whole have the same change trend except for Ampicillin and Cefotaxime, whose resistance change with time and evident in the outside, and XQ had a similar situation. There is a special phenomenon in July to September, during this time, antibiotic resistance rate in 2 lakes in all percentages increased greatly, the maximum resistance to basic all appear at this time, especially concentrate in September. It may be related to the rainfall in Xi 'an during that period. Rainfall is likely to help antibiotic resistant bacteria and antibiotic resistance genes to landscape water. Studies have found that rainfall will increase the abundance of antibiotic resistant bacteria and antibiotic resistance genes in a storm drain (Ahmed et al.,2018), thereby causing microbial pollution to downstream water (Newton et al.,2019). At the same time, reclaimed water is used to irrigate the soil around the landscape water, resulting in certain antibiotic resistance genes and antibiotic resistant bacteria in the soil (Wang et al.,2014; Han et al.,2016), under the scour of rain, these soil pollutants will enter the landscape water, thus increasing the content of antibiotic resistant bacteria in the water. On the detection of resistance rate, FQ and XQ lake also appear similar situation, SMZ, AMP and CTX antibiotic resistant bacteria detection rate is higher than that of TET and CIP, the AMP and CTX antibiotic resistant bacteria detection rate is on the top, Whole detection rate order from high to low was AMP > CTX > SMZ > TET > CIP. Experiments of water resistance phenotype from the 2 out of 80 strains also side confirmed the results. The existence of antibiotics in water will lead to resistance of bacteria in water under pressure selection (Xu et al.,2016). Meanwhile, the antibiotic resistance rates in 2 lakes were found to be high in summer and winter on the whole, which was similar to the situation in the other study (Huang et al.,2019). In this study, a content difference test of 5 types of antibiotic resistance bacteria was conducted and the results found that 3 kinds of antibiotic resistance bacteria content (Ampicillin, Ciprofloxacin and Sulfa) are not relatively large differences It can be concluded that 2 lakes of different water supplement water sources will not lead to antibiotic resistant bacteria content in the landscape water are different.

Based on the detection of antibiotic resistance rate in the early stage, 80 strains of antibiotic resistant bacteria were screened out from 2 lakes through an antibiotic sensitivity test, and the distribution of antibiotic resistant patterns of these antibiotic resistant bacteria was very similar. The phenotype resistant to AMP-CTX is the most, accounting for more than half of the antibiotic resistant phenotype, which is a very interesting phenomenon. In previous reports, resistance to 1 antibiotic is more common, while such a wide range of double-resistance is rare. Moreover, in this study, the AMP-resistant phenotype was common and detected in almost all antibiotic resistant bacteria, which indicated that AMP-resistant phenotype was dominant in 2 lakes.

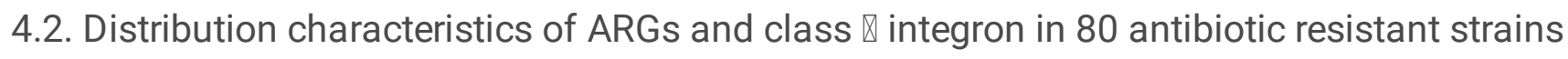




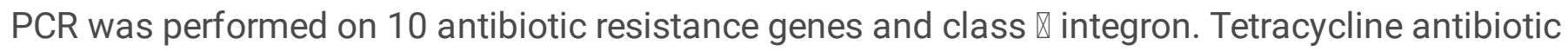
resistance genes had a high detection rate, among which tetA and tetG genes were the main coding genes. Bacterial resistance to antibiotics mainly develops resistance to antibiotics through changing the target of antibiotic action, efflux pumps antibiotic mechanism, inactivating or inactivating enzymes of antibacterial antibiotics, changing pore protein to prevent antibiotic penetration, and changing antibiotic metabolic pathways (Tong et al.,2012). However, the occurrence of tetracycline antibiotic resistance is generally due to the efflux pumps shielding target or the enzyme inactivation required by antibiotic antibiotics. The mechanisms of the two Tetracycline resistance genes with the highest detection rate are both efflux pumps mechanism, and efflux pumps mechanism is the most common antibiotic resistance in tetracycline resistance. Studies on winter rivers in Shijiazhuang, China found that tetA and other genes were detected in natural water (Luo et al.,2019), and the detected amounts in rivers and sediments were different. Some studies have found that Sulfonamides, tetracycline and integron genes are ubiquitous in the sediments in the estuary and coastal areas of the Yangtze river(Lin et al.,2015), and the content of Sulfonamides, Tetracycline and integron genes show a trend of decline from the estuary to the coast. It can be found that Tetracycline resistance genes are quite widespread, and efflux pumps Tetracycline resistance genes are dominant. The detection rate of $\beta$-lactam resistance genes was relatively low, except for a small number of detected genes, most antibiotic resistance patterns strains did not detect the corresponding genes, which was consistent with some studies (Jiang et al.,2019). It is speculated that in addition to the tested genes, there may be other corresponding resistance genes (Knapp et al., 2012). However, in this study, only 3 types of $\beta$-lactam resistance genes were selected, which makes the solid detection has certain limitations. It was also found that although Tetracycline and Sulfonamides resistance genes were detected in both antibiotic resistance bacteria in 2 lakes, the prominent points of these 2 antibiotic resistance genes were different. The tet $G$ had the highest detection rate of Tetracycline in the FQ lake, and Sulfonamides had the highest su/2 rate, while XQ lake corresponds to tetA and su/1. This may be related to genetic original mobile int higher detection rate, int》 as the carrier, in the dissemination of resistance genes play an important role (Uyaguari et al., 2013). Researchers have found that the int $t$ in natural water such as the river has a high correlation with antibiotic resistance genes detection rate and a low correlation in the wastewater treatment plant (Ma et al., 2017). Although suspended substances in water were not detected in this study, suspended substances in landscape water, such as algae and micro plastics, might influence the spread of antibiotic resistance genes together with integron (Fang et al., 2018; Fang et al., 2018). The test of int $t$ detection rate more than $90 \%$, it is highly possible that rainfall also led to a increase in the content of integrons in lake, leading to the difference in the major antibiotic resistance genes found in the 2 lakes, which is similar to some studies (Chen et al., 2019), and the detailed reasons need to be further studied.

\subsection{Distribution characteristics of antibiotic resistance strains genera}

The identification of 80 strains of antibiotic resistant bacteria showed that Bacillus cereus and Escherichia coli were the main strains. Bacillus cereus as a kind of conditionally pathogenic bacteria can cause food poisoning. It can be detected in the food and clinical scenario, but little document reported it in water environment (Zhuang et al., 2013). The reports on the distribution of Bacillus cereus in the water- 
supply plant were studied and we found that conventional technology has a better removal effect (Jiang et al., 2018). Other studies tested the antibiotic resistance of 60 strains of food-borne Bacillus cereus in Guizhou, China, and found that they were resistant to Ampicillin, Trimethoprim, and Cefepime, which could not be used as clinical therapeutic antibiotics for food-borne diseases caused by Bacillus cereus (Zhou et al., 2019). Humans will be exposed to these Landscape water to a large extent, and may even inhale aerosols containing antibiotic resistance bacteria (Pal et al., 2016), which may increase the possibility of human infection with pathogenic bacteria. As an intestinal microorganism, Escherichia coli has been monitored as a water pollution indicator, and excessive drainage in sewage plants will lead to the increase of antibiotic resistant Escherichia coli in water (O 'flaherty et al., 2019). Recent studies have shown that the spread of antibiotic resistance genes in water may be mainly caused by faeces, rather than the environmental pressure selection (Karkman et al., 2019), so the most common type of Escherichia coli in excrement and urine, are thought to be most likely to spread as a source of bacteria. The Escherichia coli existing in the human intestinal tract, its resistance can be transferred to those bacteria of intestinal symbiotic medium which were originally sensitive to antibiotics (Ham et al., 2012). In this study we found in the detection of multiple resistance, Escherichia coli were resistant to AMP and other 3 kinds of antibiotics, but only sensitive to CTX, no CTX resistant Escherichia coli existed. This may signal that Escherichia coli has a high sensitivity to CTX. It may also be the reason that CTX resistance gene detection rate is low in 2 lakes leading to a low shifting level, detailed reason needs further exploration. Most of the remaining identified antibiotic resistant bacteria are not pathogenic bacteria, but they can transfer antibiotic resistance genes to pathogenic bacteria through horizontal gene transfer. Tests also found a small amount of other pathogenic bacteria such as Pneumonia klebsiella, Pseudomonas aeruginosa, and Staphylococcus aureus, they exist in landscape water, providing opportunities that the pathogenic bacteria may be possible to acquire resistance genes. Conditional pathogenic bacteria and pathogenic bacteria, after enters the human body, can increase the use of antibiotics of treatment, cause multiple antibiotic resistance superbug to appear (Alicia et al., 2018), pose a potential health risk for humans. Bacterial resistance can be divided into intrinsic resistance and acquired resistant. In this study, among 80 antibiotic resistant bacteria, most of them were acquired resistance, few of them were intrinsic resistance. 9 strains were identified as intrinsic resistance, including 3 genera like Klebsiella pneumoniae, Pseudomonas aeruginosa, and Stenotrophomonas maltophilia, which needs to be further enriched by subsequent studies.

\subsection{Effects of water quality indexes on the content of antibiotic resistant bacteria in landscape water}

The physical and chemical properties of water as a routine indicator may affect the situation of antibiotic resistant bacteria in water. However, in this analysis of the correlation between water quality detection indexes and antibiotic resistant bacteria, except that the change of water temperature correlated with the concentration of antibiotic resistant bacteria in SMZ and CTX in 2 lakes, only the content of total phosphorus had a significant impact on the concentration of antibiotic resistant bacteria in ampicillin in lake FQ. The remaining water quality indexes do not affect the concentration of antibiotic resistant bacteria in the 2 lakes. The content of ampicillin antibiotic resistant bacteria in the water can be reduced by controlling the content of total phosphorus.

Page 14/24 


\section{Conclusion}

The results of this study showed that antibiotic resistant bacteria and antibiotic resistance genes were detected in 2 different landscape waters. Moreover, it was found that the surface water nor the reclaimed water was used as the replenishment source of the landscape water, it would not affect the species and content of antibiotic resistance genes and bacteria in the landscape water, indicating that the reclaimed water as the replenishment source was not the transmission source of antibiotic resistance genes. Through the identification of microbial species, we found that the antibiotic resistant bacteria in landscape water were highly concentrated in several types of bacteria. Moreover, it was found through analysis that the removal of total phosphorus was correlated with some antibiotic resistant bacteria, and the changes of other conventional water quality indexes would not affect the content of antibiotic resistant bacteria. The results of this study can provide references for further assessment of the risk of antibiotic resistant bacteria and antibiotic resistance genes in landscape waters and the impact of regenerated water on water replenishment.

\section{Declarations}

\section{Ethics approval and consent to participate}

Not applicable.

\section{Consent for publication}

Not applicable.

\section{Availability of data and materials}

All data generated or analysed during this study are included in this published article [and its supplementary information files].

\section{Competing interests}

The authors declare that they have no competing interests.

\section{Funding}

This study was supported by the National Natural Science Foundation of China (NSFC) (Grant No. 51578441), and National Key Research and Development Project (No. 2017YFE0127300), and the Key Research and Development Project of Shaanxi Province (No.2020ZDLNY06-07).

\section{Authors' contributions}

YQL sorted out all the data and writing the manuscript; CMZ provided the idea of this study and was a major contributor in writing and modifying the manuscript $₫ X M$ analyzed the water samples.; PPZ 
collected the water samples.; JL help the investigation; ZW help the investigation. All authors read and approved the final manuscript.

\section{Acknowledgements}

This study was supported by the National Natural Science Foundation of China (NSFC) (Grant No. 51578441), and National Key Research and Development Project (No. 2017YFE0127300), and the Key Research and Development Project of Shaanxi Province (No.2020ZDLNY06-07).

\section{References}

Alicia, B., Sofia, R.C., Itziar, A., Manuel, E.,2018. When Humans Met Superbugs: Strategies to Tackle Bacterial Resistances to Antibiotics. Biomolecular concepts,9(1),216-226. DOI: 10.1515/bmc-2018-0021

Ahmed, W., Zhang, Q., Lobos, A., Senkbeil, J., Sadowsky, M. J., Harwood, V. J., Saeidi, N., Marinoni, O., Ishii, S. (2018). Precipitation influences pathogenic bacteria and antibiotic resistance gene abundance in storm drain outfalls tapping in coastal sub - tropical waters. The Environment International, 116, 308-318. DOI: 10.1016/j.envint.2018.06.031

Chen, A, B, W., Yang, Y., Liang, X, M., 2013. Metagenomic profiles of antibiotic resistance genes (ARGs) between the human impacted estuary and deep ocean sediments. The Environmental Science \& Technology,47 (22), 12753-12760. DOI: 10.1021/es403818e

Cui, Q., Fang, T., Huang, Y., Dong, P., Wang, H.,2016. Evaluation of bacterial pathogen diversity, abundance and health risks in urban recreational water by amplicon next-generation sequencing and quantitative PCR. Journal of Environmental Sciences, 57,137-149. DOI: 10.1016/j.jes.2016.11.008

Cynthia, W. L., Katharina, L.,2016. Antibiotic resistance Genes in Freshwater Biofilms May Reflect Influences the from High - Intensity Agriculture. The Microbial Ecology, 72 (4), 763-772. DOI:

$10.1007 / \mathrm{s} 00248-016-0740-x$

Chen, Y., Su, J. Q., Zhang, J., Li, P., Chen, H., Zhang, B., Gin, K.Y., He, Y.,2019. High-throughput profiling of antibiotic resistance gene dynamic in a drinking water river-reservoir system. Water research, 149, 179189. DOI: $10.1016 /$ j.watres.2018.11.007

Chen, Y, W., Chen, K, N., Hu, Y, H., 2006. Discussion on possible error for phytoplankton chlorophyll - a concentration analysis using hot - ethanol extraction method. The Journal of Lake Sciences, 2006 (5), 550-552.DOI: CNKI:SUN:FLKX.0.2006-05-020

Dong, P., Cui, Q., Fang, T., Huang, Y., Wang, H.,2019. Occurrence of antibiotic resistance genes and bacterial pathogens in water and sediment in urban recreational water. Journal of Environmental Sciences, 77 (3), 68-77. DOI: 10.1016/j.jes.2018.06.011 
Elmahdy, M. E. I., Fongaro, G., Magri, M. E., Petruccio, M. M., Barardi, C. R. M.,2016. Spatial distribution of enteric viruses and somatic coliphages in a lagoon used as drinking water source and recreation in southern brazil. International Journal of Hygiene and Environmental Health, 169(7),617-625. DOI: 10.1016/j.jheh.2016.07.009

Fothergill A. W.,2012. Antifungal Susceptibility Testing: Clinical Laboratory and Standards Institute (CLSI) Methods. In:Hall, g. (eds) Interactions of Yeasts and Moulds, and Antifungal Agents. The Humana Press. 30-35. DOI: 10.1007/978-1-59745-134-5_2

Fothergill A. W.,2015. Antifungal susceptibility testing: Clinical Laboratory and Standards Institute (CLSI) the methods [J]. Journal of Clinical Microbiology Newslet - ter, 18 (21), 161-167.

Fewtrell, L., Kay, d. 2015. Recreational water and infection: a review of recent findings. Current Environmental Health Reports, 2(1), 85-94. DOI: 10.1007/s40572-014-0036-6

Fang, T.T., Cui, Q.J., Huang, Y., Dong, P.Y., Wang, H., Liu, W. T., Ye, Q. H.,2018. Distribution comparison and risk assessment of free-floating and particle-attached bacterial pathogens in urban recreational water: implications for water quality management. Science of The Total Environment, 613-614, 428-438. DOI: 10.1016/j.scitotenv.2017.09.008

Fang, T.T., Wang, H., Cui, Q. J., Rogers, M., Dong, P. Y.,2018. Diversity of potential antibiotic resistance bacterial pathogens and the effect of suspended particles on the spread of antibiotic resistance in urban recreational water. Water Research, 145, 541-551. DOI: 10.1016/j.watres.2018.08.042

Gao, P., Mao, D., Luo, Y., Wang, L., Xu, B., Xu, L.,2012. Occurrence of sulfonamide and tetracyclineresistance bacteria and resistance genes in aquaculture environment. Water Research, 46(7), 0-2364. DOI: 10.1016/j.watres.2012.02.004

Guo, X.P., Liu, X., Lu, D.P., Zhao, S., Sun, X.L., Wu, j. y., Chen, Y.R., Tou, F.Y., Hou, L., Liu, M., Yang, Y., 2018. Seasonal and spatial distribution of antibiotic resistance genes in the sediments along the Yangtze Estuary, China. The Environmental Pollution, 242 (A), 576-584. DOI: 10.1016/j.envpol.2018.06.099

Huang, H.W., Zeng, S.Y., Dong, X., Li, D., Zhang, Y., He, m., Du, P. F.,2019. Diverse and an abundant antibiotics and antibiotic resistance genes in an urban water system. Journal of Environmental Management, 231, 494-503. DOI: 10.1016/j.jenvman.2018.10.051

Hlavsa, M. C., Roberts, V. A. Kahler, A. M., Hilborn, E. D. Mecher, T. R., Beach, M. J., et al.,2015. Outbreaks of illness associated with recreational water - the United States. American Journal of Transplantation, 64(24), 668-672. DOI: 10.1111/ajt.13473

Harnisz, M.,2013. Total resistance of native bacteria as an indicator of changes in the water environment.Environ.Pollut.174,85-92. DOI: 10.1016/j.envpol.2012.11.005 
Harnisz, M., Korzeniewska, E.,2018. The prevalence of multidrug-resistance, Aeromonas spp. in the municipal wastewater system and their dissemination in the environment. Science of The Total Environment, 626, 377-383. DOI: 10.1016/j.scitotenv.2018.01.100

Helena, S.O., Giulia, A., Gertjan, M., 2015. Quantification of waterborne pathogens and associated health risks in urban water. Environmental Science \& Technology,49(11), 6943-6952. DOI:

10.1021/acs.est.5b00625

He, T., Xiong, J, Q., Wang, X, C., Liu, Y, Z., 2016. Quality variations of landscape water with marketers the wire of reclaimed water supply. Chinese Journal of Environmental Engineering, 10 (12), 6923-6927. DOI: 10.12030/j.cjee.201508006

Han, X. M., Hu, H. W., Shi, X. Z., Wang, J. T., Han, L. L., Chen, D.L., He, J.Z., 2016. Impacts of reclaimed water irrigation on soil antibiotic resistance in urban parks of Victoria, Australia. Environmental Pollution, 211, 48-57. DOI: 10.1016/j.envpol.2015.12.033

Ham, Y. S., Kobori, H., Kang, J. H., Matsuzaki, T., lino, M., Nomura, H.,2012. Distribution of antibiotic resistance in urban watershed in japan. Environmental Pollution, 162(none), 98-103. DOI:

10.1016/j.envpol.2011.11.002

Jiang, L., Hu, X., Xu, T. L., Zhang, H.C., Shen, D., Yin, D.Q., 2013. Prevalence of antibiotic resistance genes and their relationship with antibiotics in the Huangpu River and the drinking water sources, Shanghai, China. The Science of the Total Environment,458-460267-272. DOI: 10.1016/j.scitotenv.2013.04.038

Jiang, Q. J., Huang, H., Wang, C. P., Chen, Q. H., Yi, L. X., Wang, M. F.,2018. Spatial and Temporal Distribution of Bacillus sp. and Its Spores in Conventional Process Waterworks. China Water \& Wastewater,34(5),10-14.

Karkman, A., Pärnänen, K., Larsson, D.G.J.,2019. Fecal pollution can explain antibiotic resistance gene abundances in anthropogenically impacted environments. Nature Communications 10(1), 1-8. DOI: $10.1038 /$ s41467-018-07992-3

Knapp, C.W. and Lima, L., Olivares - Rieumont, S., Bowen, E., Werner, D., Graham, D.W.,2012. Seasonal variations in antibiotic resistance gene transport in the Almendares River, Havana, Cuba. Frontiers in Microbiology 3, 396. DOI: 10.3389/fmicb.2012.00396

Low, A., Ng, C., He, J.,2016. Identification of antibiotic resistance bacteria community and A GeoChip based study of resistance in urban watersheds, Water Research, 106,330-338. DOI:

10.1016/j.watres.2016.09.032

Lin, L., Yuan, K., Liang, X.M., Chen, X., Zhao, Z.S., Yang, Y., Zou, W., Luan, T.G., Chen, B.W.,2015. The effects and distribution of sulfonamide and tetracycline resistance genes in the Yangtze river estuary and nearby coastal area. Marine Pollution Bulletin, 100(1), 304-310. DOI: 10.1016/j.marpolbul.2015.08.036 
Luo, X., Zhang, w. L., Xu, M., Zhang, Y., Jiang, Y. F., He, L., Zhong, W. Z., 2019. Correlation between Antibiotic Resistance Genes and Microbial Community in Winter Rivers. Environmental Science \& Technology, 42 (5), 20-26.DOI: 10.19672/j.cnki.1003-6504.2019.05.004

Luo, Y., Xu, L., Rysz, M., Wang, Y., Zhang, H., Alvarez, P. J.J.,2011. Occurrence and transport of tetracycline, sulfonamide, quinolone, And macrolide antibiotics in the Haihe river basin, China. Environmental Science \& Technology, 45(5), 1827-1833. DOI: 10.1021/es104009s

Ma, L., Li, A.D., Yin, X.L., Zhang, T.,2017. Prevalence of Integrons as The Carrier of Antibiotic resistance Genes in Natural and Man - Made Environments. Environmental Science \& Technology, 51(10), 57215728. DOI: $10.1021 /$ acs.est.6b05887

McConnell, M. M., Lisbeth, T. H., Jamieson, R. C., Neudorf, K. D., Yost, C. K., Anthony,T.,2018. Removal of antibiotic resistance genes in two tertiary level municipal wastewater treatment plants. The Science of The Total Environment, 643, 292-300. DOI: 10.1016/j.scitotenv.2018.06.212

Novo, A., Andre, S., Viana, P. Nunes, O. C., Manaia, C.M.,2013. Antibiotic resistance, antimicrobial residues and bacterial community composition in urban wastewater. Water Research,47 (5), 1875-1887. DOI: 10.1016/j.watres.2013.01.010

Newton, R. J., McClary, J. S., 2019. The flux and impact of wastewater infrastructure microorganisms on human and ecosystem health. Current Opinion in Biotechnology, 57145-150. DOI:

10.1016/j.copbio.2019.03.015

O'Flaherty, E., Solimini, A., Pantanella, F., Cummins, E., 2019. The potential human exposure to antibiotic resistance-Escherichia coli through recreational water. Science of The Total Environment,650(1),786-795. DOI: 10.1016/j.scitotenv.2018.09.018

Pruden, A., Pei, R., Storteboom, H., Carlson, k. H.,2006. Antibiotic resistance genes as emerging contaminant: Studies in northern Colorado t. Environmental Science \& Technology, 40(23), 7445-7450. DOI: $10.1021 /$ es060413l

Pal, C., Bengtsson-Palme, J., Kristiansson, E., Larsson, D. J.,2016. The structure and diversity of human, animal and environmental resistomes. Microbiome, 4(1), 54-68. DOI: 10.1186/s40168-016-0199-5

Pang, Y., Huang, J., Xi, J., Hu, H., Zhu,Y.,2016. Effect of ultraviolet irradiation and chlorination on ampicillin - resistance Escherichia coli and its ampicillin hold gene. Frontiers of Environmental Science \& Engineering, 10 (3),522-530. DOI: 10.1007/s11783-015-0779-9

Tong, J., Wei, S. Y.,2012. State - of - the - art removal of antibiotic resistance bacteria (ARB) and antibiotic resistance gene (ARG) in wastewater treatment the plants (WWTPs). Acta Scientiae Circumstantial, 32 (11), 2650-2659. DOI: 10.13671/j.hjkxxb.2012.11.010 
Tan, L., Wang, F., Liang, M., Wang, X., Das, R., Mao, D., Luo, y.,2019. Antibiotic resistance genes attenuated with salt accumulation in saline soil. Journal of Hazardous Materials, 374, 35-42. DOI:

10.1016/j.jhazmat.2019.04.020

Uyaguari, M. I., Scott, G. I., Norman, R. S.,2013. Abundance of class 1-3 integrons in south Carolina estuarine ecosystems under high and low levels of anthropogenic influence. Marine Pollution Bulletin, 76(1-2), 77-84. DOI: 10.1016/j.marpolbul.2013.09.027

Wang, F. H., Qiao, M., Lv, Z., Guo, E. G., X., Jia, Y., Su, Y. H., Zhu, Y, J.,2014. Impact of reclaimed water irrigation on antibiotic resistance in public parks, Beijing, China. Environmental Pollution, 184(1), 247-253. DOI: 10.1016/j.envpol.2013.08.038

Xu, Y., Guo, C.S., Luo, Y., Lv, J. P., Zhang, Y., Lin, H.X., Xu, J., 2016. Occurrence and distribution of antibiotics, antibiotic resistance genes in the urban rivers in Beijing, China. Environmental Pollution, 213, 833-840. DOI: 10.1016/j.envpol.2016.03.054

Zhao, S., Gao, X, L., Zhang, C, G., Zhou, J., Gan, Y, P., 2011. Research on maintenance technology of urban reclaimed water for landscape, Environmental Engineering, 29 (6), 5-7 + 11. DOI:

10.13205/j.hjgc.2011.06.015

Zhang, C, M.. Xu, L, M., Mou, X., Xu, H., Liu, J., Miao, Y, H., Wang, X, C, C., Li, X, C., 2019. Characterization and evolution of antibiotic resistance of Salmonella in municipal wastewater treatment plants. Journal of Environmental Management, 251, 109547. DOI: 10.1016/j.jenvman.2019.109547.

Zhang, C, M., Du, C., Xu, H., Miao, Y, H., Cheng, Y, Y., Tang, H., Zhou, J, H., Wang, X,C.,2015. Occurrence of tetracycline-resistance fecal coliforms and their resistance genes in an urban river impacted by municipal wastewater treatment plant discharges. Journal of Environmental Science and Health, Part A, 50(7), 744749. DOI: $10.1080 / 10934529.2015 .1011995$

Zhuang, Z. H., He, L., Guo, Y. C., Pei, X. Y., Fu, P., Wang, X. Y., 2013. Virulent gene profiles and antibiotic susceptibility of foodborne Bacillus cereus in China. Chinese Journal of Food Hygiene,25(3),198-201. DOI: $10.13590 /$ j.cjfh.2013.03.017

Zhou, Q., Zhou, L., Tian, P., Xiang, J. S.,2019.,Virulence Genes and Drug Resistance of Food-borne Bacillus cereus in Guizhou ,China. Modern Preventive Medicine,46(11),2019-2023.

\section{Figures}



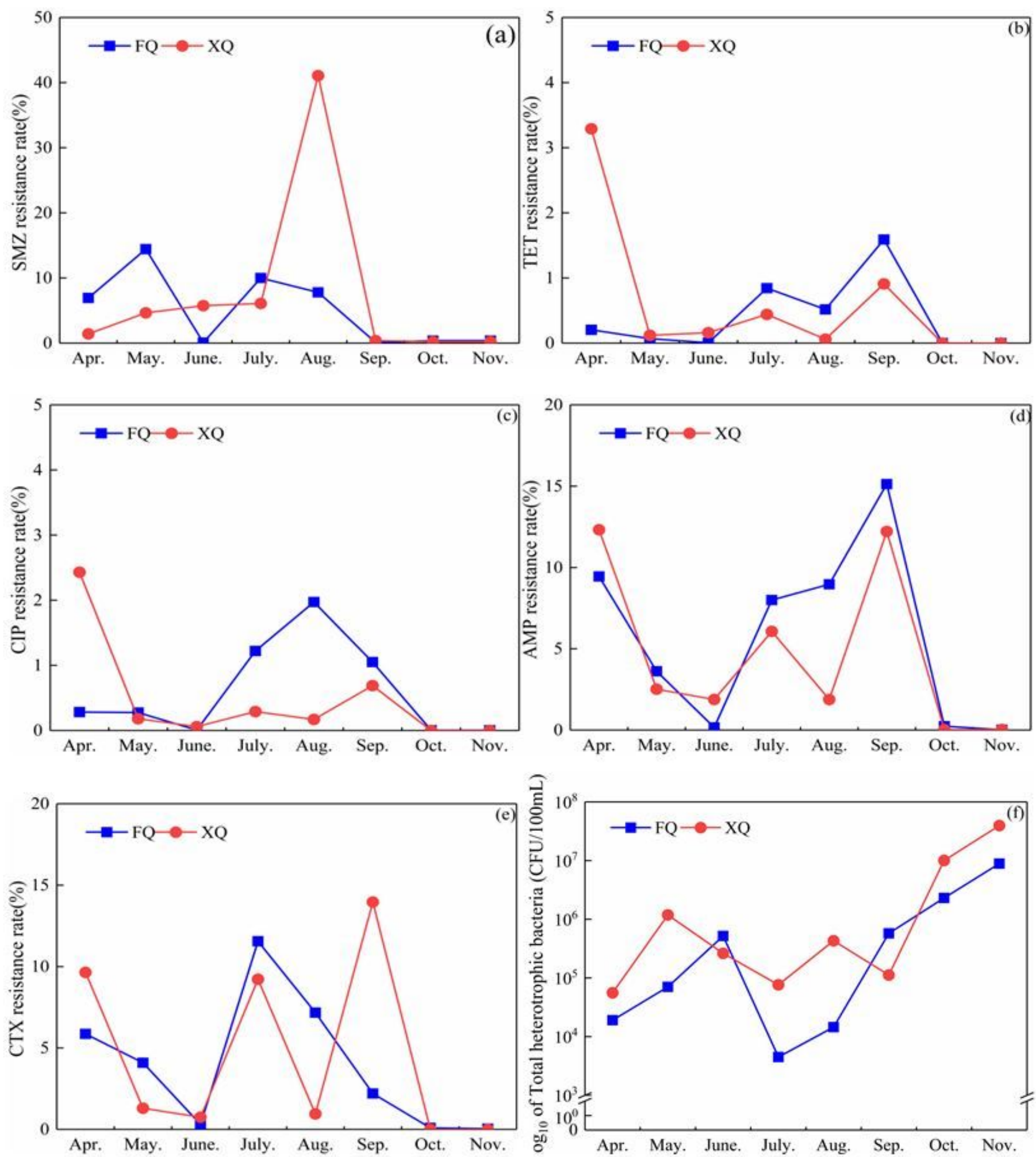

\section{Figure 1}

Temporal changes of 5 kinds of antibiotic resistance bacteria rate and total heterotrophic bacteria changes in water taken along the FQ and XQ lake (a):SMZ;(b):TET;(c):CIP;(d):AMP;(e):CTX;(f):Total heterotrophic bacteria. 

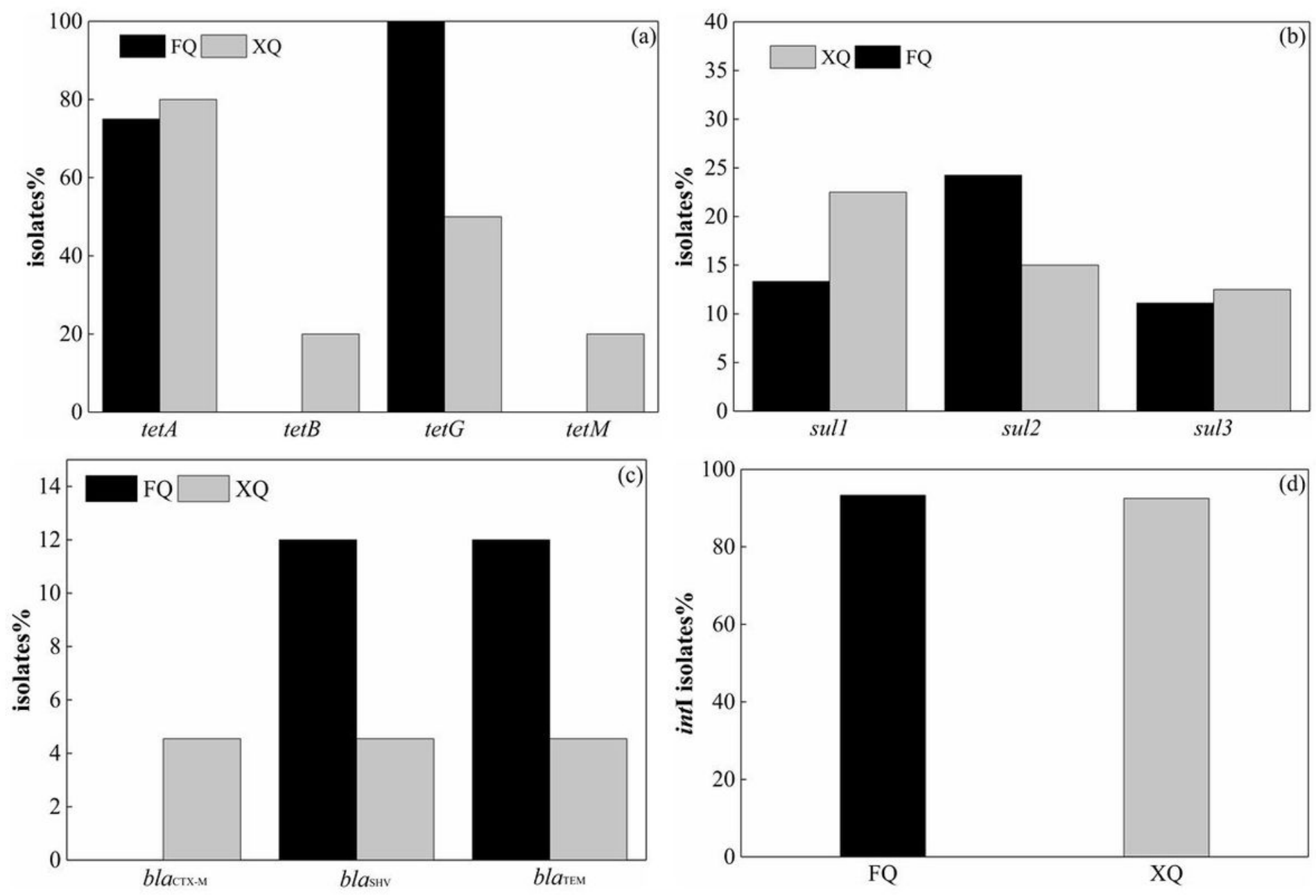

Figure 2

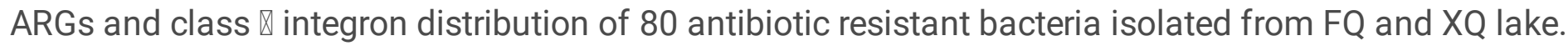
The prevalence of (a)Tetracycline resistance genes; (b)Sulfa resistance genes; (c) $\beta$-lactam resistance genes; (d)class $\otimes$ integron 


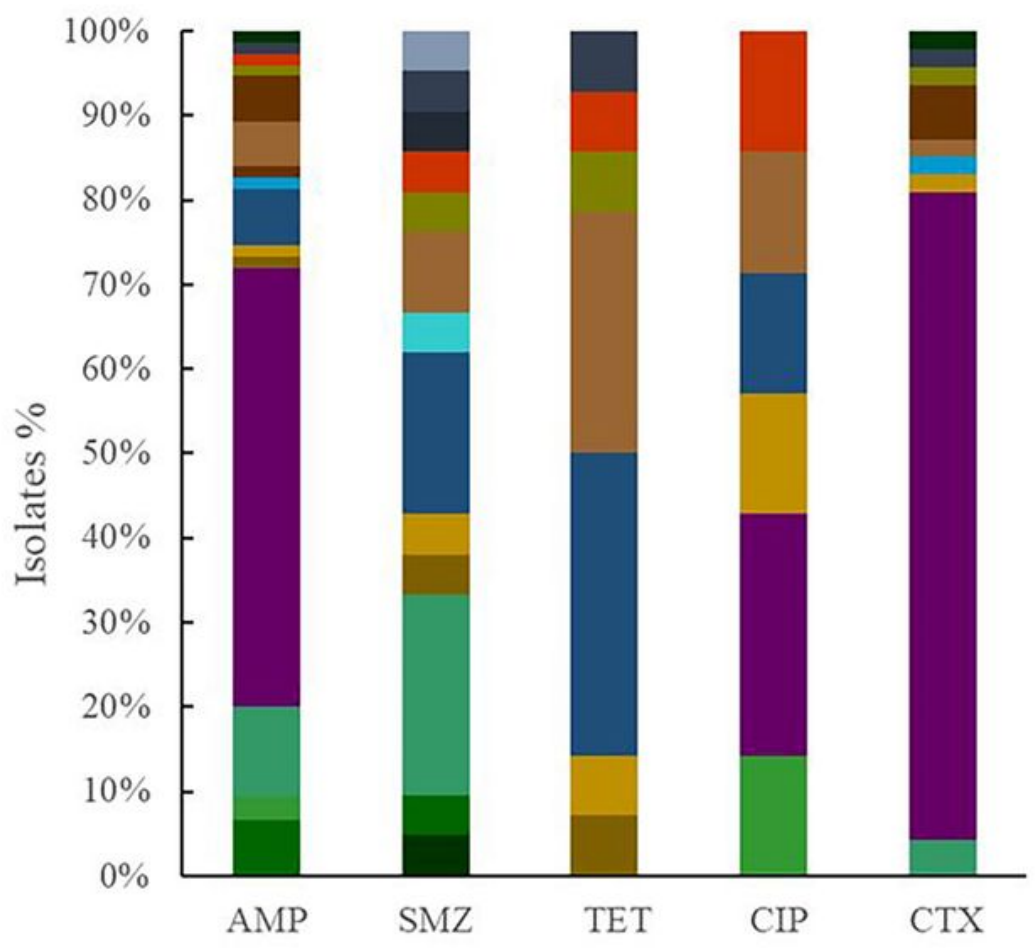

- Acinetobacter lwoffii

- Aeromonas caviae

- Aeromonas hydrophila

aeromonas veronii

- Bacillus cereus

- Citrobacter braakii

a Citrobacter freundii

- Escherichia coli

- Exiguobacterium acetylicum

Exiguobacterium sibiricum

- Klebsiella oxytoca

- Klebsiella pneumoniae

- Pseudomonas aeruginosa

- Pseudomonas putida

- Raoultella ornithinolytica

- Staphylococcus epidermidis

- Staphylococcus haemolyticus

- Staphylococcus hominis

- Stenotrophomonas maltophilia

- Klebsiella pneumoniae

- Escherichia coli

= Citrobacter freundii

- Raoultella ornithinolytica

- Bacillus cereus

- Staphylococcus haemolyticus

- Pseudomonas putida

- Citrobacter braakii

\section{Figure 3}

a. Identified genera containing 80 antibiotic resistance bacteria. b. Identified genera of multiple-antibiotic resistance bacteria. 3 pattern: 3 antibiotic resistance patterns; 4 pattern: 4 antibiotic resistance patterns; 5 pattern:5 antibiotic resistance patterns. 


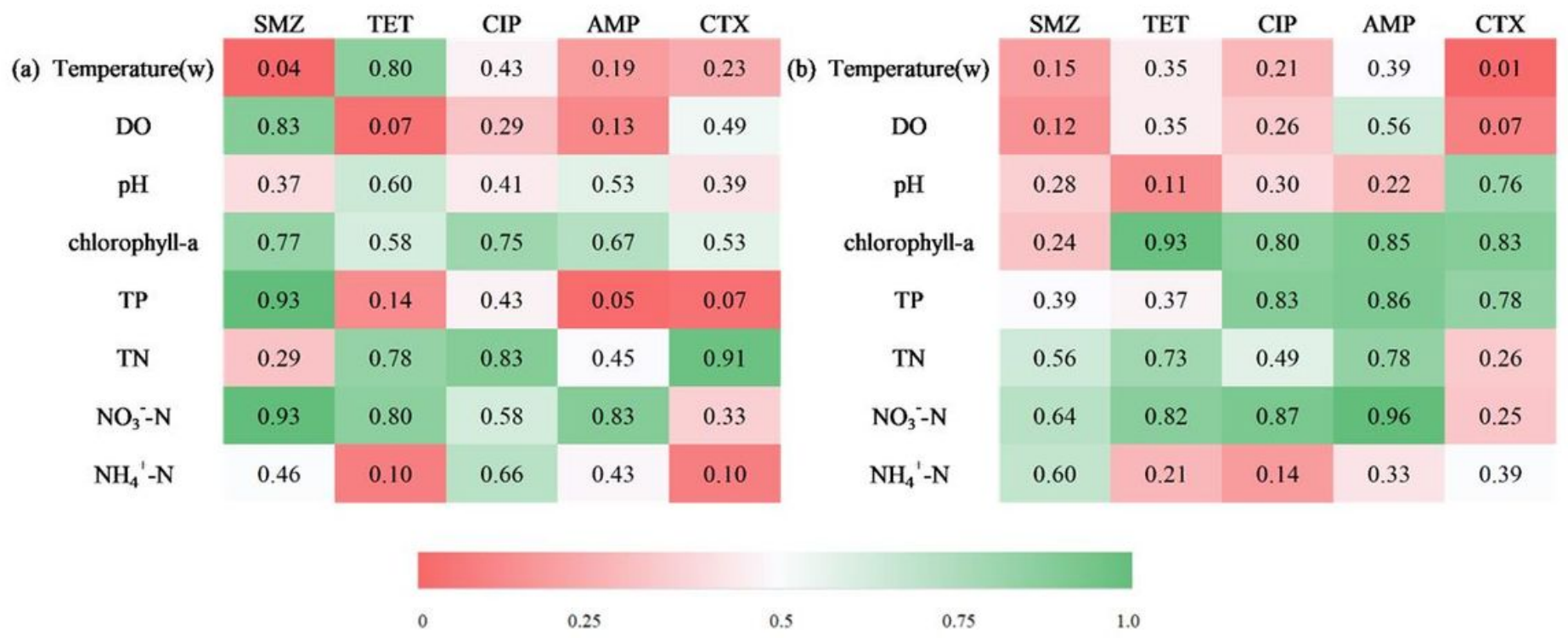

\section{Figure 4}

Spearman correlations among antibiotic resistance bacteria abundance and water quality parameters in 2 lakes. (a):FQ lake;(b)XQ lake.

\section{Supplementary Files}

This is a list of supplementary files associated with this preprint. Click to download.

- SupplementaryMaterial.doc 